\title{
HISTORY OF POLIOMYELITIS IN CORNWALL AND DEVON
}

BY

\author{
A. H. GALE, \\ Department of Medicine, University of Bristol, \\ and \\ E. P. HARGREAVES, \\ Public Health Department, County of Cornwall
}

\section{INTRODUCTION}

Though it was begun quite independently, this paper may be regarded as an extension of the work of Benjamin and Logan (1953). They have studied the distribution of notifications of poliomyelitis in Great Britain as a whole, whereas we have examined a smaller area in detail.

The present study was undertaken for several reasons:

(i) Cornwall and Devon are pre-eminently the "holiday" counties of England, and are visited by large numbers every summer. Most of the visitors spend their holiday in a coastal resort but many stay inland in a farmhouse or camp. It seems reasonable to suppose that, if importation of infection is a potent factor in the origin of epidemics, the seaside towns should show some preponderance of cases over the years.

(ii) The two counties had one of the earliest severe epidemics of poliomyelitis recorded in England-that of 1911. In that year

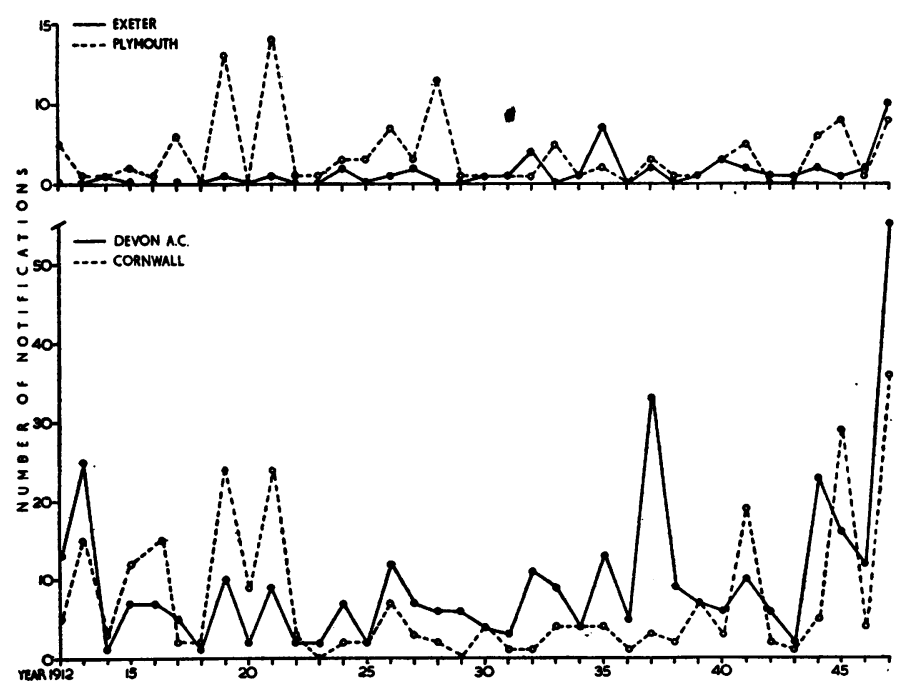

Fio. 1.-Annual notifications of poliomyelitis in Cornwall A.C., Devon A.C., Exeter C.B., and Plymouth C.B., 1912-47.
154 cases were reported in the two admininistrative counties (Cornwall, 42; Devon, 108) up to September 16, and there were more later. In addition, some seventy cases were reported by Soltau (1911), in the towns which now make up the county borough of Plymouth. The distribution of cases up to September 16, 1911, in the two counties was reported in detail by Reece (1912) and the later cases were described by the County Medical Officers of Health for Cornwall and Devon. No cases were reported in the county borough of Exeter. Between 1919 and 1946 (Fig. 1) there appear to have been no generalized outbreaks, but there were some local ones which are of interest when considered in relation to what came before and after and to what was happening elsewhere in England. In 1947 there was a generalized epidemic in England as a whole and in both counties more cases than usual were reported, but on the whole, incidence was lower than might have been expected. After the general lull of 1948 , however, the attack rates in 1949 and 1950 in both counties were higher than in England and Wales as a whole. (Table I, opposite.)

Fig. 1 suggests that there may have been some persistence. of activity for several years after 1911 and some renewal of it before 1947. When compared with the true epidemic years, this activity was slight and has therefore passed unnoticed.

(iii) Cornwall and Devon have certain advantages over most other counties of England for the study of the distribution of disease. There is a reasonably sharp distinction between urban and rural 
TABLE I.

NOTIFICATION RATES OF POLIOMYELITIS PER 10,000 LIVING IN ENGLAND AND WALES, CORNWALL A.C., DEVON A.C., EXETER C.B., AND PLYMOUTH C.B., FOR INDIVIDUAL YEARS 1947-52, AND MEAN ANNUAL RATE FOR 6 YEARS 1947-52

\begin{tabular}{l|c|c|c|c|c|c|c}
\hline \multicolumn{1}{c|}{ Area } & 1947 & 1948 & 1949 & 1950 & 1951 & 1952 & $\begin{array}{c}\text { Mean } \\
\text { Annual } \\
\text { Rate } \\
1947-52\end{array}$ \\
\hline England and & & & & & & & \\
$\quad$ Wales . & 1.8 & 0.4 & 1.4 & 1.8 & 0.6 & 0.9 & 1.1 \\
Cornwall A.C. & 1.1 & 0.6 & 3.5 & 2.9 & 1.1 & 0.6 & 1.6 \\
Devon A.C. & 1.1 & 0.4 & 1.8 & 3.5 & 1.0 & 1.2 & 1.5 \\
Exeter C.B. & 1.4 & 0.8 & 0.8 & 3.4 & 0.5 & 1.3 & 1.4 \\
Plymouth C.B. & 0.4 & 0.2 & 1.0 & 1.5 & 1.2 & 0.4 & 0.8 \\
\hline
\end{tabular}

(N.B.-Rates for individual years calculated from the RegistrarGeneral's estimated populations for each year, mean annual rates from populations given in the preliminary report on the 1951 census.)

conditions, lines of communications are not quite so complicated as in most other counties, and the holiday resorts may be distinguished from areas predominantly concerned with some local industry. Such distinctions are never absolute, but in these two counties they are fairly definite.

Unfortunately, information about the occurrence and distribution of cases of poliomyelitis is very unequal for the whole period, but from 1912-30 we have records of the cases reported in the two administrative counties and in the two county boroughs (Exeter and Plymouth). The records are summarized in Fig. 1. From 1931 onwards we have information about the number of cases reported each year in every sanitary district. For some years there is a little more, and for the years from 1947 considerably more, detailed information about distribution. In reviewing the whole story, one is struck by the frequency with which the disease seems to appear in almost the same, but not quite the same areas at intervals sometimes of many years. One is also struck by the comparatively small number of cases reported in the big seaside resorts like Torquay and Paignton, and by the fact that the outbreaks have tended to occur either in rather out-of-the-way parts like Holsworthy or in small industrial towns like Newton Abbot and St. Austell. It is convenient to divide the description into three parts:

(1) the epidemic of 1911,

(2) the inter-epidemic period, 1912-46,

(3) the recent epidemic period, 1947-52.

\section{EPIDEMIC OF 1911}

When we compare the epidemic of 1911 with more recent experience we have to make certain allowances. Although sporadic cases of the disease had been described for many years, epidemics were only just beginning in Great Britain. The districts in N.W. Devon and N.E. Cornwall, which were chiefly affected, must then have been a great deal more remote than they are now, and even to-day Holsworthy R.D., which had the highest attack rate of any county district, is very much off the beaten track. There was at that time no compulsory notification of poliomyelitis; in fact the events of 1911 here and elsewhere, were the chief reason for the introduction of compulsory notification. It therefore seems likely that, according to present-day standards, the reporting of cases was defective and that many cases which would now be counted as poliomyelitis were then overlooked. There is a little indirect evidence of this in the report of Reece (1912), for 34 of the 154 patients for whom he obtained details died. A case mortality rate of $22 \cdot 1$ per cent. is rather more than double that which is usual nowadays. Even if we take Reece's figures at their face value the attack rate in the Holsworthy R.D. $(59 \cdot 8$ per 10,000$)$ was extraordinarily high. Table II, modified from Reece's report, shows the distribution of the known cases by sanitary districts on a geographical basis with rates per 10,000 population for districts with five or more cases.

TABLE II

(Modified from Reece, 1912)

A.-PRINCIPAL FOCI IN N.W. DEVON AND N.E. CORNWALL

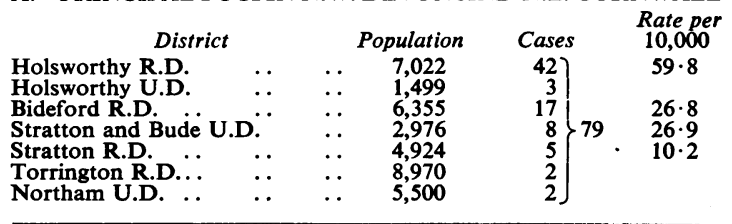

B.-LESSER FOCI. 1. SOUTH MOLTON AND BarNSTAPLE

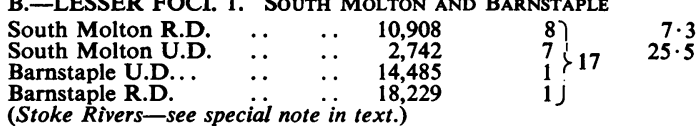

2. Newton ABвOT

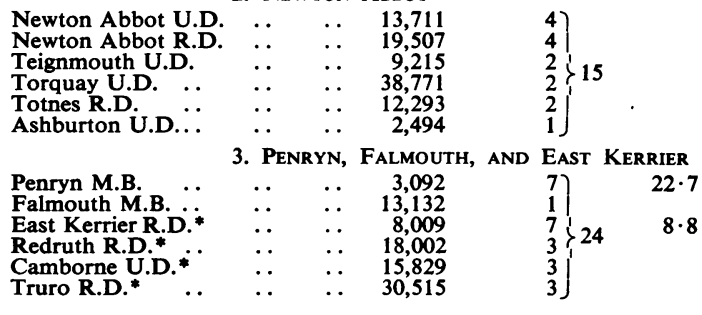

C.-SCATTERED CASES DEVON

Crediton R.D.

Crediton R.D. Exmouth U.D.

Honiton R.D..

Tavistock R.D.

Tavistock U.D.

Tiverton R.D...

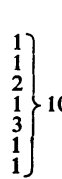
CORNWALL

Bodmin R.D. .

Launceston R.D.

Launceston U.D.

10 Newquay U.D. St. Austell R.D.

$\cdots$

* There have been considerable changes in Local Government Divisions in Cornwall since 1911. 
Fig. 2 shows the geographical relationships of the administrative areas.

The first case in Devon was noted on May 3, 1911, in Holsworthy U.D., and the first in Cornwall on May 27, 1911, in Penryn U.D. The outbreak in Penryn was described by Gregor and Hopper (1911).

Some of these rates are very high and the only county district which has experienced a higher rate in recent years is the small town of Fowey, which had fifteen cases in 1950 (64 per 10,000).

Reece's account is incomplete in that it ends with the week ending September 16, 1911, when eleven cases were reported. There were more cases in both counties after Reece's departure, but those in Cornwall are of particular interest, because it is clear from the County Medical Officer's Report for 1911 that St. Austell U.D. and R.D. and Truro U.D. and R.D. were involved in the later stages of the epidemic. The later figures for these areas are:

St. Austell R.D., 13; U.D., 3. Truro U.D., 1; R.D., 5.

It is possible to reconstruct a general picture of the distribution of the known cases in the 1911 epidemic from Reece's report and the Annual Report of the County Medical Officers of Health for 1911 as follows:
The main focus was .in Holsworthy R.D. with offshoots to the West at Bude and to the North in the parishes of Hartland and Clovelly (Fig. 3, opposite). Within Holsworthy R.D. cases were concentrated in a relatively small number of parishes:

(1) in Holsworthy itself, in the parishes of Thornbury and Cookbury to the north east and in Clawton and Pyworthy to the south;

(2) in W. Putford and Bradworthy.

No cases were reported from large areas of Holsworthy R.D. and several instances of multiple cases in one household were reported (see Fig. 3, inset).

The lesser foci were:

(a) South Molton with extension along the main road to Barnstaple and possibly to Stoke Rivers.*

(b) Penryn and East Kerrier with extension north to Camborne and possibly east to Truro and St. Austell though it is not clear whether St. Austell should be regarded as a separate focus.

(c) Newton Abbot and the South Devon coast towns of Exmouth, Teignmouth, Torquay, Totnes.

- Reece includes in his report (p. 42) an account of a localized outbreak of an illness resembling non-paralytic poliomyelitis in the village of Stoke Rivers (Barnstaple R.D.) between August 21 and September 30,1911 . In this village with a population of 119 no less than 36 persons had fairly definite attacks and nine others possible attacks. Reece's account has some similar features to that given by Hargreaves (1949) of the events at N. Tamerton in July, 1947, though there three paralytic cases occurred.

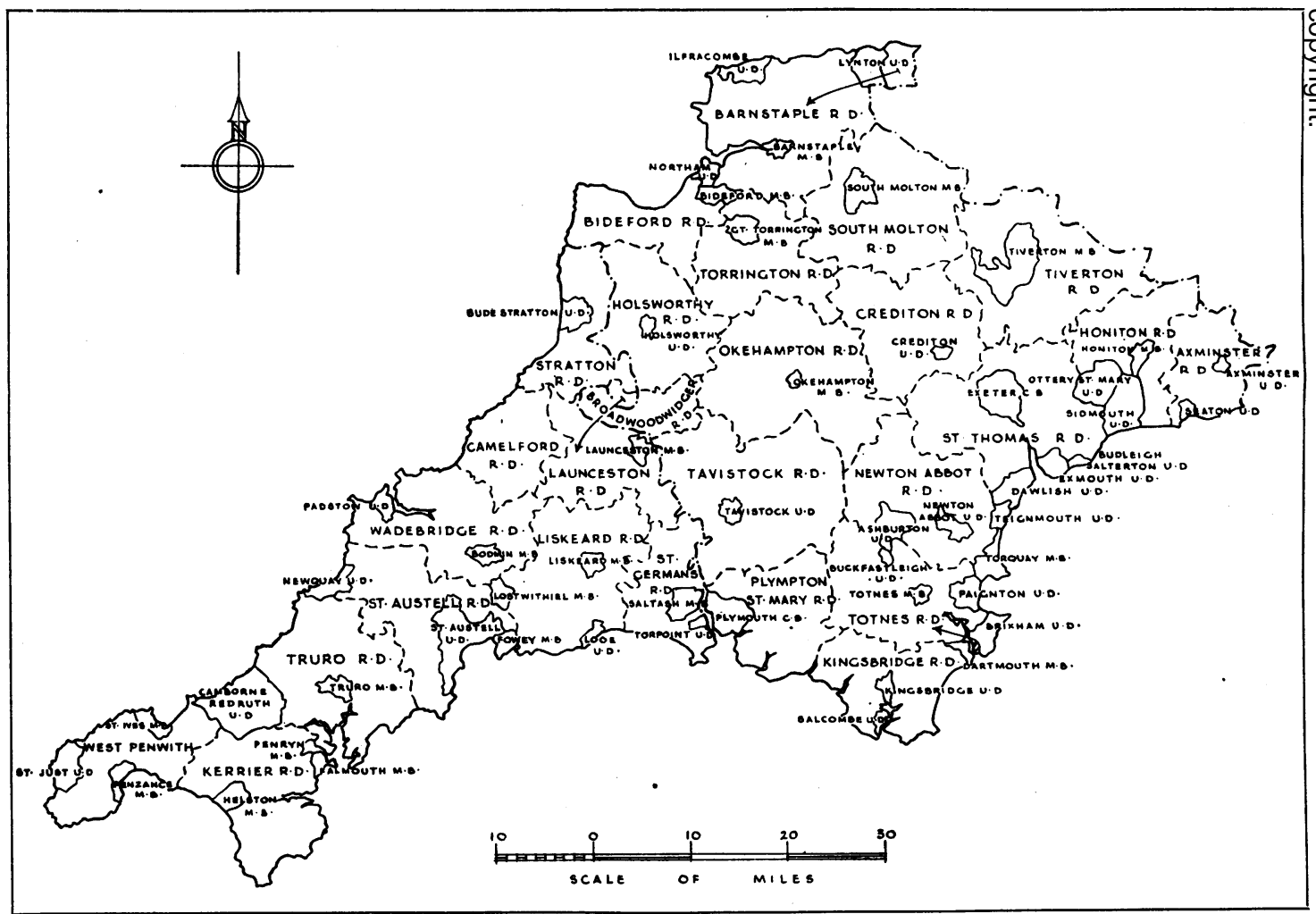

Fig. 2.-Administrative areas of Cornwall and Devon (Key Map). 


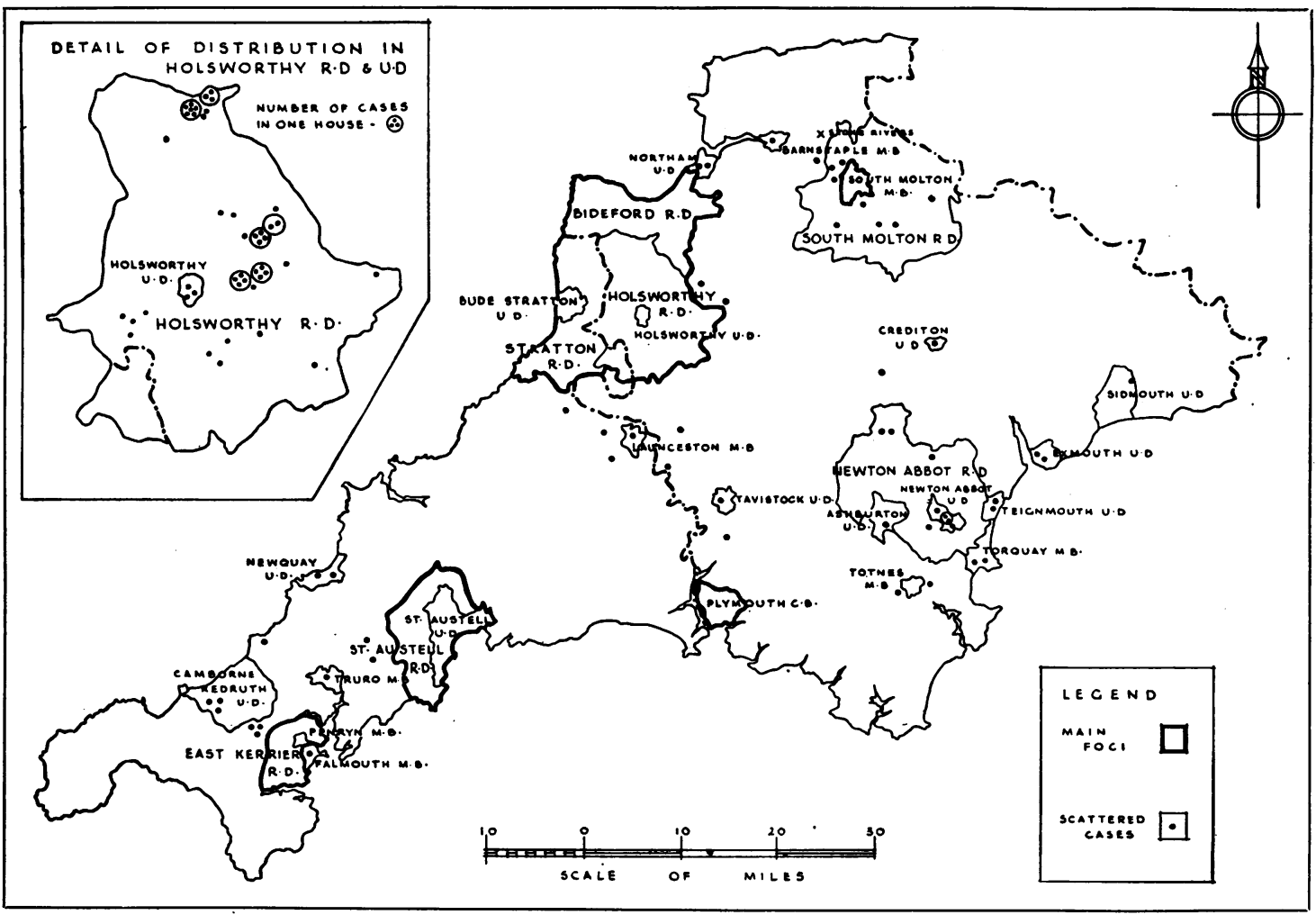

FIG. 3.-Distribution of poliomyelitis, 1911 (modified from Reece, 1912).

Outbreak in Plymouth.-In 1911, what is now the county borough of Plymouth was divided administratively into the county boroughs of Plymouth and Devonport and the urban district of E. Stonehouse with an aggregate population of about 207,000 as compared with the population of Plymouth of about 220,000 in 1951. Soltau (1911) said that he knew of 73 cases in the three towns and considered that this was far fewer than the actual number. He laid stress on the fact that the cases were scattered all over the three towns and that there seemed to be no relation between high prevalence and bad social conditions. If anything the better part of Plymouth suffered more severely and some of the poorest parts very little.

The outbreak in Plymouth began in July, later than in Holsworthy, and went on until October, in which month a few isolated cases occurred. That is all the epidemiological information we have about this outbreak, but it does suggest that incidence must have been considerably higher-than it has ever been since.*

There were no cases in Exeter.

* The highest number of cases reported in Plymouth in any year from 1912 to 1952 was 31 in 1950.
When the available information has been examined, the general impressions are:

(1) that it was more localized than epidemics have been in recent years,

(2) that the areas chiefly affected were rather those having little contact with the rest of England than the holiday resorts,

(3) that attack rates in some of the districts affected were quite as high as those which have since occurred, even in years like 1949 and 1950.

It is difficult to imagine how a distribution of cases such as that of 1911 could have resulted from immediate importation of infection by holidaymakers, particularly in view of the primitive communications which existed at that time in these two counties.

INTER-EPIDEMIC Period, 1912-46.

(a) 1912-36. - After the epidemic of 1911 came a long period during which poliomyelitis never became sufficiently prevalent in the two counties to excite comment in the Annual Reports of the County Medical Officers. For a few years after the first world war, the figures of annual notifications for Cornwall and Plymouth were somewhat high but 
they never reached thirty in one year in either county (Fig. 1). It is possible that the figures for these years may have been affected by the prevalence of the then "new" disease encephalitis lethargica, which caused some confusion in the statistics of epidemic diseases of the central nervous system at the time.

In Cornwall the rather high figures for 1919 (24) and for 1921 (24) were associated with a similar prevalence in Plymouth. The areas chiefly affected were St. Germans R.D., Liskeard R.D., and Calstock R.D. (now part of St. Germans R.D.).

The year 1926, in which occurred the epidemic in the schools of Broadstairs, Kent, was one of relatively high incidence in many parts of Great Britain, but Devon and Cornwall were only slightly affected (Fig. 1). Between 1922 and 1936 there were never more than ten annual notifications in either county and usually there were fewer. In 1923 and 1929 there were none in Cornwall. The Registrar-General did not begin to publish figures of notifications in county districts in his Annual Review until 1931 and so it is not easy to find the details of distribution within the counties before that year. There is little of note to be found in the figures of distribution by districts of the few cases notified in the years 1931-36.

(b) 1937-46. - In 1937 there was a small localized epidemic in Devon. The outbreak began in a village called Drewsteignton which lies in the angle between the trunk road A.30 and the main road A.382 from Whiddon Down-Moretonhampstead-Newton Abbot-Torquay-Paignton. The village is just off both roads-about a mile $S$. of A.30 and 4 miles E. of A.382 (Fig. 4). There were six cases in Drewsteignton and a series of cases in places on either side of A.382 - two at Moretonhampstead, two at Lustleigh, one at Manaton, three at Hennock, one at Widdecombe, one at Kingsteignton, and one at Denbury. Four cases were reported in Torquay, and two of these, in a preparatory school, were associated with a case in Hennock. At about the same time (September-October) as this group of cases, there were widely scattered cases in other parts of the county and for the whole year the Registrar General gives 33 notifications for the Administrative County, three for Plymouth, and two for Exeter. It should be remembered that 1938 was the year of epidemic prevalence in England and Wales as a whole and that this incident in Devon preceded that prevalence.

Neither Cornwall nor Devon seems to have been affected by the epidemic of 1938 .

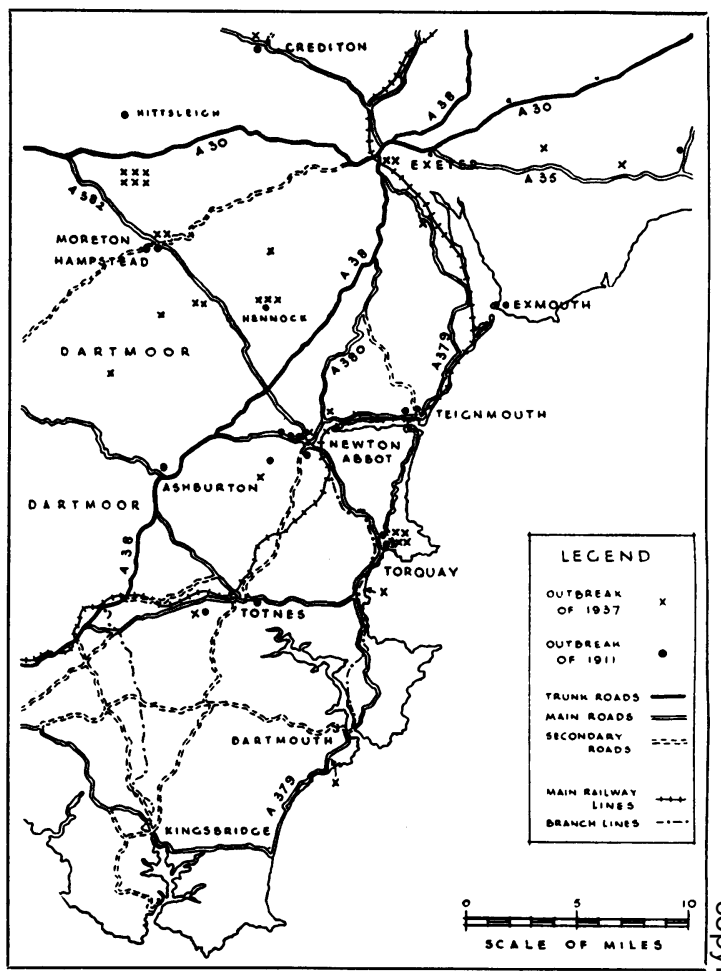

FIG. 4.-Distribution of poliomyelitis in the Newton Abbot and Southe Devon area, 1937. Figures for 1911 are also shown for comparison.

In the war years there were no incidents sufficiently important to arouse comment at a time when everyone was pre-occupied with other matters, but a study of the notification returns produces some small points of interest in the light of events which came after:

In Cornwall in 1941 there were nineteen notifications with three each in St. Austell U.D., St. Germans R.D., and Truro R.D., and two each in Liskeard U.D., and St. Austell R.D. In 1945 there were 29 notifications in the county with seven in Kerrier R.D., six in CamborneRedruth U.D., and two each in Bodmin, Falmouth, St. Austell U.D., Camelford R.D., and W. Penwith R.D. In Devon in 1944 there were 23 notifications, with five in Torquay, four in Ottery St. Mary, and two each in Paignton, Barnstaple R.D., and Plympton St. Mary R.D.

The experience of the inter-epidemic period may therefore be summarized as follows:

1919-21. - There is a little evidence of rather high prevalence in Plymouth and in the neighbouring rural districts of E. Cornwall.

1937.-There was a localized outbreak in Devon affecting the S.E. corner of Okehampton R.D., and Newton Abbot R.D. immediately to the S. of it.

1945. - There were 29 notifications in Cornwall, with seven in Kerrier R.D., and six in CamborneRedruth U.D. 


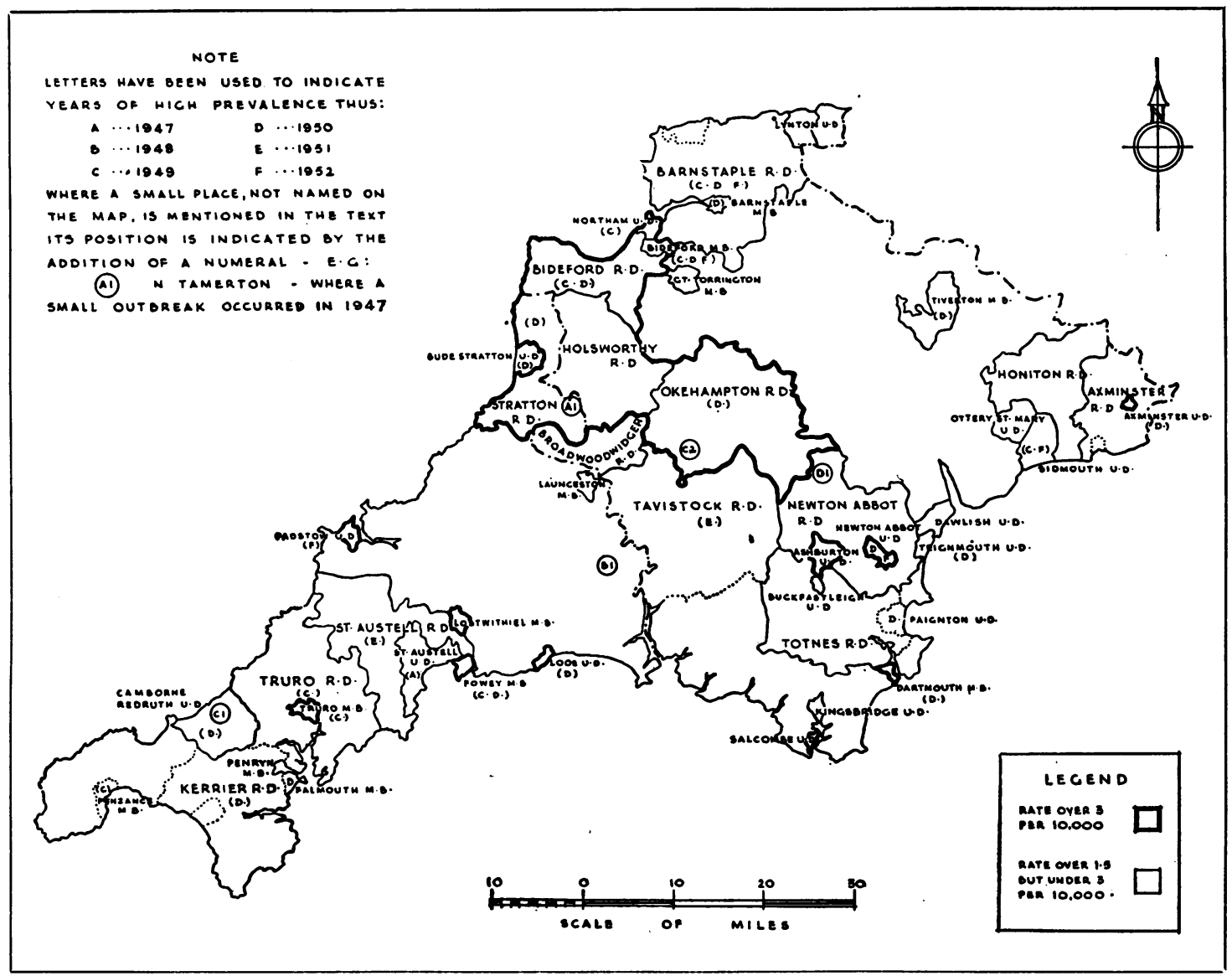

Fig. 5.-Distribution of poliomyelitis, 1947-52. Mean annual rates of notifications and localized epidemics.

Recent EPIDEmic Period, 1947-52

In England and Wales as a whole the year 1947 was one of great change in the epidemiology of poliomyelitis. In Cornwall and Devon, Exeter and Plymouth, the change was not so marked as in other parts of the country, but there was a definite increase in notifications (Fig. 1). Although this part of England largely escaped the epidemic of 1947 , both administrative counties experienced a high incidence in 1949-50 and in these years their rates were higher than the average for England and Wales (Table I).

The mean annual rates for individual county areas and the notifications in each year are shown in the detailed Tables of the Appendix. Populations taken from the preliminary census report are also shown, since some of the areas have such small populations that a few cases produce a high rate.

Fig. 5 is intended to summarize the information in the detailed Tables and to illustrate it in geographical terms.

Some of the urban districts, in Cornwall particularly, cover quite a large area and include various villages within their boundaries. For example Camborne-Redruth U.D. includes the village of Illogan where there was a sharp outbreak in 1949.

For the whole period, Cornwall A.C. had the highest rate and both Devon A.C. and Exeter C.B. had a higher rate than that for England and Wales, but Plymouth C.B. had a rate only half that of Cornwall and substantially less than that for the whole country. There was no consistent difference in the rates for urban and rural districts, for in Cornwall A.C. the urban districts had a higher rate $(1 \cdot 8$ per 10,000$)$ than the rural districts $(1 \cdot 2$ per $10,000)$, whereas in Devon A.C. the rural districts had a slightly higher rate $(1 \cdot 5$ per 10,000$)$ than the urban districts $(1 \cdot 4$ per 10,000$)$. 


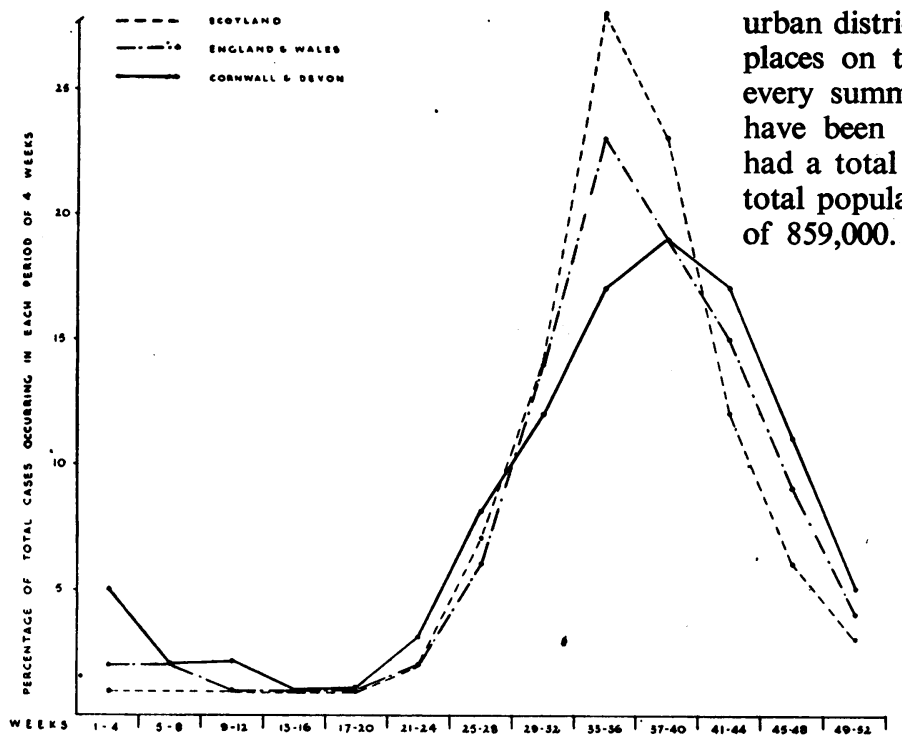

Fig. 6.-Uncorrected notifications of poliomyelitis in 4-weekly periods, 1947-51.
SEASONAL INCIDENCE.-Fig. 6 shows how the seasonal incidence of notifications in the two counties in the years 1947-51 differed from that in England and Wales and in Scotland. In Scotland, where the season of warm weather is comparatively short, 28 per cent. of notifications occurred in the 33rd-36th week period. In England only 23 per cent. occurred in this period, in Cornwall and Devon together only 17 per cent. The curve for the western counties is flatter than that for either of the others, and the poliomyelitis season begins a little earlier and lasts a little longer into the autumn and winter. This difference between North and South has been described in the U.S.A. (Serfling and Sherman, 1953).

IMPORTATION OF INFECTION.-If this is an important immediate factor in the genesis of epidemics, it would seem reasonable to expect that the ring of seaside resorts which encircle the two counties would tend to have high rates of incidence. This problem is examined in Table III. The Table is open to the objection that it takes account only of these resorts which are municipal boroughs or

TABLE III

NOTIFICATION RATES PER 10,000 LIVING 1947-52

\begin{tabular}{c|c|c|c|c|c|c|c}
\hline Year & 1947 & 1948 & 1949 & 1950 & 1951 & 1952 & $\begin{array}{c}\text { Mean } \\
47-52\end{array}$ \\
\hline "Resorts" .. & 0.9 & 0.2 & 2.4 & 3.7 & 0.6 & 1.2 & 1.5 \\
"Remainder of \\
$\begin{array}{c}\text { A.C.S" } \\
\text { A.C.s (Com- } \\
\text { bined) }\end{array}$ & 1.1 & 0.6 & 2.3 & 3.0 & 1.2 & 0.8 & 1.5 \\
\hline
\end{tabular}

There is no difference between the mean (1947-52) rates for the "Resorts" and for the counties as a whole. The figures for individual years show tha in 1947 the "Resorts" rate was a little lower thane that for the rest and in the two years of relatively low prevalence, 1948 and 1951, the "Resorts" had" definitely lower rates than the rest. The figures of notifications for these years are very small (only five notifications in the "Resorts" in 1948) and so perhaps not much should be made of them, but the difference is consistent in both years.

The figures for the individual resorts given in the Appendix Table show that the smaller ones (e.g. Fowey, Dartmouth) contributed far more notifications in proportion to their size than did the larger ones (e.g. Torquay, Paignton, Penzance). On the whole this evidence seems to be against the view that the principal resorts play any obvious part in the genesis of the epidemic.

One of us (E.R.H.) has examined the known instances of importations (i.e. persons developing obvious disease within a week of arrival) of the disease into Cornwall in the individual years 1947-52 and has summarized the information (Table IV, opposite).

It seems clear that the arrival of overt cases of poliomyelitis was not an important factor in Cornwall but this evidence of course tells us nothing about the effect of inapparent importation and for this we must turn to a more detailed consideration of events in the two counties in the individual years. 
TABLE IV

CORNWALL: KNOWN IMPORTATIONS (1947-52)

\begin{tabular}{|c|c|c|c|c|c|c|}
\hline \multirow{2}{*}{ Year } & \multirow{2}{*}{ Total Cases } & \multirow{2}{*}{ Importations } & \multicolumn{3}{|c|}{ Remarks on Importations } & \multirow[b]{2}{*}{ Recurrence } \\
\hline & & & No. & Town & District & \\
\hline 1947 & 36 & 4 & $\begin{array}{l}1 \\
1 \\
2\end{array}$ & $\begin{array}{l}\text { Portreath } \\
\text { Marazion } \\
\text { St. Ives }\end{array}$ & $\begin{array}{l}\text { Camborne-Redruth U.D. } \\
\text { W. Penwith R.D. }\end{array}$ & E \\
\hline 1948 & 19 & 0 & 一 & - & - & 一 \\
\hline 1949 & 11 & 4 & $\begin{array}{l}2 \\
1 \\
1\end{array}$ & $\begin{array}{l}\text { St. Ives } \\
\text { Megavissey } \\
\text { Marazion }\end{array}$ & $\begin{array}{l}\text { St. Austell R.D. } \\
\text { W. Penwith R.D. }\end{array}$ & $\left\{\begin{array}{l}\text { one in a child of } 3 \\
1 \text { month later but no } \\
\text { connexion traced }\end{array}\right.$ \\
\hline 1950 & $\cdot 98$ & 12 & $\begin{array}{l}3 \\
1 \\
1 \\
1 \\
1 \\
1 \\
1 \\
3\end{array}$ & $\begin{array}{l}\text { Looe } \\
\text { Lanlivery } \\
\text { Newquay } \\
\text { Manaccan } \\
\text { Padstow } \\
\text { Redruth } \\
\text { St. Blazey } \\
\text { Bude-Stratton }\end{array}$ & $\begin{array}{l}\text { St.Austell R.D. } \\
\text { Kerrier R.D. } \\
\text { St. Austell U.D. }\end{array}$ & $\begin{array}{c}= \\
= \\
\{ \\
\text { 14 cases after } \\
\text { 36-day interval }\end{array}$ \\
\hline 1951 & 36 & 3 & $\begin{array}{l}1 \\
2\end{array}$ & $\begin{array}{l}\text { Newquay } \\
\text { Pentewan }\end{array}$ & St. Austell U.D. & - \\
\hline 1952 & 21 & 1 & 1 & Falmouth & & - \\
\hline
\end{tabular}

1947-48, Cornwall.-The first cases in Cornwall occurred in July, 1947, at North Tamerton, a remote village near Holsworthy (Fig. 5, A.1). This outbreak was remarkable for the high proportion of nonparalytic cases, and bears some resemblance to that at Stoke Rivers in 1911, described by Reece (1912), which has already been mentioned. At North Tamerton, however, there were three paralytic cases whereas at Stoke Rivers there had been none. The outbreak has been described by one of us in an earlier paper (Hargreaves, 1949). It is a curious fact that these first cases occurred so near to the main focus of the epidemic of 1911 (see Figs 2 and 5.)

The second outbreak appeared in the St. Austell area early in August. The first case (August 10), was that of a girl aged 7 living at Trenoweth Mill, a very rural spot some 5 miles from St. Austell. No other case had occurred within 30 miles. There was an interval of 34 days before the second case on September 12, of a woman aged 26 who was a direct contact of the previous case, in that the little girl was in her Sunday School class. The woman worked in St. Austell, and on October 22, 40 days later, two girls, both indirect contacts of hers living in St. Austell, developed poliomyelitis. A further six cases occurred in the town in the following 3 weeks, the actual dates of onset being:

October $\quad 30-8$ days interval (one case)

November 6 (two cases)

November 10 (two cases)

November 12 (one case).
In two of the last cases, direct contact had occurred (7 days and 21 days previously); in the remaining four cases, indirect contact was probable.

The outbreak spread in a leisurely fashion eastwards along the main trunk road. In November, a case occurred at St. Blazey 3 miles east of St. Austell, and a month later two cases occurred at Lostwithiel, 7 miles east of St. Austell, and one case at East Taphouse, still further to the east.

Callington (Fig. 5, B.1) lies on the same trunk road, 31 miles east of St. Austell, and here at the turn of the year an explosive outbreak occurred. In all, there were six cases, five probably infected from the same source, since they developed paralysis between December 29, 1947, and January 2, 1948; the sixth, a secondary case, occurred on January 11 , 1948, 8 days later.

1947-48, Devon.-- In Devon there were no such definite groups of cases as there were in Cornwall, but the following districts stand out a little from the rest as having reported an unusually large number of cases:

\begin{tabular}{|c|c|c|c|}
\hline URBAN & $\begin{array}{c}\text { DisTRICTs - Newton Abbot U.D. } \\
\text { Torquay M.B. }\end{array}$ & $\begin{array}{l}\cdots \\
\cdots\end{array}$ & \\
\hline URAL & $\begin{array}{c}\text { DisTRICTS- Holsworthy R.D. } \\
\text { Newton Abbot R.D. } \\
\text { St. Thomas R.D. } \\
\text { Tavistock R.D. . }\end{array}$ & $\begin{array}{l}\cdots \\
\cdots \\
\cdots\end{array}$ & . \\
\hline
\end{tabular}

Torquay has a population of 53,216 , so perhaps four notifications are not so very remarkable. St. Thomas R.D. is also a populous district, since 
it includes the suburbs of Exeter, and Exeter had a slightly higher attack rate than Devon A.C. in 1947 (Table I). Holsworthy R.D., the main focus of the epidemic of 1911, reported five cases in a population of only 6,196 .

Allen-Price (1952) described the distribution of cases in West Devon (Tavistock U.D. and R.D., Okehampton U.D. and R.D., and Broadwoodwidger R.D.) over the period 1937-51; writing of 1947 he says:

Ten cases occurred in nine parishes with many miles and poor communications separating them. Once again there was no spread from the individual cases, with the exception of two cases in the same family at Peter Tavy, a small village some 4 miles from Tavistock.

In 1948 there was virtually nothing to report in Devon, and Newton Abbot R.D. was the only district which reported as many as three cases (see Appendix Table).

1949-50, Cornwall.-This was the worst period that Cornwall has yet experienced. 111 cases were confirmed in 1949, giving an incidence of 3.5 per 10,000. In 1950 there were 98 cases. Four interesting localized outbreaks occurred at Illogan, CamborneRedruth, Fowey, and Truro (see Fig. 5; Illogan C.1).

(i) Illogan is a village some 3 miles from Camborne. Three children were attacked on June 21 and all had paralysis. Two were pupils at the Illogan Infants School, and the third, a child of three, had an elder sister there. After an interval of some 7-10 days, five secondary cases occurred all intimately connected with the school, four being pupils, and direct contacts of the initial cases, and the fifth a child of $2 \frac{1}{2}$, who had a brother at the school. The source of the original cases was not discovered but subsequent spread was probably by personal contact at the school.

(ii) Outbreaks occurred in Camborne and Redruth almost simultaneously, and in both some connection with Illogan cases was easily demonstrated. At Redruth the original three cases had all been to Illogan by bus 10 days before the onset. At Camborne, the first patient was a cousin of an Illogan patient, and his mother, the patient's aunt, in spite of warnings, had visited him on two occasions, the last being 8 days before the onset of paralysis. The outbreaks thus begun, resulted in a further twelve cases.

(iii) Two serious outbreaks occurred in Fowey in successive years. The town (population 2,300) had in 1949 eight cases of poliomyelitis (incidence 35 per 10,000), and in 1950 a further fifteen cases (incidence 64 per 10,000). The outbreak of 1949 came to the surface in August when five children developed paralytic poliomyelitis within $48 \mathrm{hrs}$ of one another. Secondary cases numbered only three, all being personal contacts with the original cases. The origin of the primary cases was not found. Although the outbreak at Fowey did not show itself until August, three visitors who had been staying in the town in July developed paralytic poliomyelitis within 5 days of returning to their several homes in Cambridge, London, and Scunthorpe. In 1950 a more severe outbreak occurred; the first case developed symptoms on September 2, and between this date and the first week of November fourteen more cases occurred in the town and three in the immediate neighbourhood. All but two patients were of school age or under, and were directly or indirectly associated with the local school.

(iv) There were no cases of poliomyelitis in Truro (population 12,851) during 1947. In the autumn of 1948 , three cases, two of which proved fatal, occurred amongst boarders at a boys' school in the town. In 1949 the city was heavily attacked; two paralytic cases were reported on September 11, and in the subsequent 10 days twelve more cases were admitted to the County Isolation Hospital. In all, nineteen cases occurred in the city and seven secondary cases in the surrounding villages. Paralysis was severe, particularly in early cases, three of the first five being fatal. The outbreak in Truro City presents certain interesting features:

(a) the high age group attacked-52 per cent. of the patients were over 15 years of age,

(b) no history of direct or indirect contact with previous cases could be obtained.

Bude-Stratton U.D. and Stratton R.D. (combined population 11,352) include the small towns of Budes Stratton, and Marhamchurch, forming a triangle with sides approximately $1 \frac{1}{2}$ miles long (population 5,230 ), and the surrounding coast and countryside (population 6,122). In 1947 there was the outbreak at North Tamerton already mentioned and in subsequent years, the incidence in this urban district and the surrounding rural areas was heavy. In 1949 there were five cases, in 1950 seventeen, in 1951 two, in 1952 two.

The first case was notified on September 29, 1949, when a boy aged $7 \frac{1}{2}$ was admitted to Exeter with paralysis of both lower limbs. 12 days later, a father and son, both contacts of the first patient, contracted the disease, and the father subsequently died. Another contact became infected on November 16, 1949. The fifth case to be notified was a school child who at routine inspection was found to have a weak arm. The date of onset was uncertain.

In 1950, the first three cases were imported: two were soldiers from a nearby territorial camp, and the third was a girl in a visiting circus. All developed the disease within 4 days of arrival in the Bude area. The subsequent fourteen cases which occurred in October, 36 days after the last of the imported cases, and during the first 3 weeks

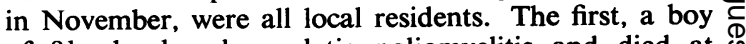
of $8 \frac{1}{2}$, developed paralytic poliomyelitis and died at $\stackrel{\oplus}{\rightarrow}$ Plymouth I.D. Hospital the following day. The case is of special interest as this is the same child who in 
1949 was admitted to hospital with paralysis of the two lower limbs. His baby brother, 9 months old, developed a mild attack 6 days later, but the remaining three children in the house were unaffected.

The spacing of cases again suggests contact spread and the possibility was borne out by definite history of contact in five of the first six cases.

The 321 Cornish cases in the years 1947-52 included twelve instances of paralytic poliomyelitis occurring in two members of the same household, and two instances of three cases occurring in one household. If non-paralytic cases diagnosed at home on clinical symptoms are included, the number of multiple infections is much greater.

Of these multiple cases, in six instances the two cases developed paralysis within $24 \mathrm{hrs}$. of each other, in eight instances the interval was between 4 and 9 days, in one case a 20-day interval occurred, and in one the third child was not affected until the following year.

Three of these multiple cases were of special interest:

(i) In 1949 a Dutchman, his English wife, and three children aged $5 \frac{1}{2}, 4 \frac{1}{2}$, and 3 years, were occupying an overcrowded condemned three-roomed cottage in one of the older parts of Fowey. Early in August, the youngest child developed poliomyelitis; the two older children, who had been in intimate contact with the sick child developed symptoms suggestive of abortive attacks of poliomyelitis, but were not taken to hospital. During the spring of 1950 , the family moved to a new Council house high up on the outskirts of the town. In October, 1950, the two older children developed poliomyelitis, the interval between onset being 5 days. The old house vacated by this family was not pulled down, but was taken by a young married couple with three children. The wife, a woman of 30 , died of poliomyelitis in November, 1950.

(ii) A Truro man aged 27 was taken ill on September 9, 1949, and died 2 days later of respiratory paralysis. There were three other siblings in the family, all grown up, and they were all at home at the time of his illness. A brother, a naval officer stationed in Plymouth, was in Truro on a week's leave and assisted in nursing him. He returned to Plymouth and went down with a mild attack of poliomyelitis on September 30. An unmarried sister who helped in the clerical work of the family business and had been in close contact with the brother who had died, was taken ill on September 25, and developed paralysis of all four limbs with diaphragmatic involvement on September 29. The remaining brother, also in the Navy, was unaffected. The history of this family illustrates how infective poliomyelitis virus can sometimes be.

(iii) A woman was delivered of her second child on September 1; apart from slight pyrexia on September 14, the puerperium was uneventful. She was up in the house from September 15-19, but did not feel very fit. On September 20 she was feverish with nausea and headache; next day she was no better and as the baby was also off colour and feverish it was decided to begin artificial feeding. The mother remained in bed until September 28, when on getting up she first noticed a weakness in her left leg, which proved to be poliomyelitis. Artificial feeding was easily established, but on September 25 and 26 the baby had four convulsions and subsequently developed some weakness in the muscles of the shoulder girdle.

Recurrent infection in the same house leads to the idea of the possibility of persistent carrier state; the following incidents are suggestive though they may be due to chance.

(i) Padstow.-In October, 1949, a girl of 7 developed an illness diagnosed as non-paralytic poliomyelitis, but not notified as such. In August, 1950, a child living in the next house but one developed poliomyelitis. Both families moved, the former to Tintagel (but keeping a flat at their Padstow house), and the latter out of the county. In January, 1952, a boy of 12 who had come to live in the second house developed poliomyelitis. He was also a friend of the first original case, and met her on her frequent visits to the Padstow flat. Almost at the same time, a girl living in Tintagel but at boarding school in mid-Wales, who was an acquaintance of the first patient, developed poliomyelitis 4 days after returning to school. In none of the incidents cited, was poliomyelitis prevalent in the area.

(ii) St. Ives.-In January, 1950, a married woman developed paralytic poliomyelitis whilst in Malta; she returned to England 2 years later and stayed in St. Ives at the house of her married sister. Within a month the sister was admitted to hospital with paralytic poliomyelitis. This was the only case of poliomyelitis in St. Ives at the time.

(iii) Fowey.-The history of the Dutchman's house already cited in the notes on multiple cases.

1949-50, Devon.-In 1949 incidence in Devon was slightly higher than that in the country as a whole, but considerably lower than that in Cornwall (Table I). In June, 1949, there was an explosive outbreak in the village of Bridestowe, Okehampton R.D. (Fig. 5, C.2), which occurred at almost the same time as that at Illogan (Fig. 5, C.1). This event has been described in some detail by Allen-Price (1952), according to whom there were thirteen cases between June 17, and July 12 . Evidently two of these were not notified as the official return for Okehampton R.D. for 1949 gives eleven cases (see Appendix Table). The village of Bridestowe, population about 550, lies on the trunk road A.30 and on the N.W. edge of Dartmoor. The trunk road carries a very large volume of holiday traffic, but 
the outbreak occurred very early, at a time when the seasonal rise in notifications in the country as a whole had only just begun. The attack rate was very high and Allen-Price states that 18 per cent. of the child population was affected. This was the most important localized outbreak in Devon in 1949, but the districts of the N.W. round Bideford and Barnstaple and the town of Sidmouth had a high incidence.

The rate in $1950(3 \cdot 5$ per 10,000$)$ was the highest recorded for the Administrative County, and the County Borough of Exeter also had its highest incidence $(3 \cdot 4$ per 10,000$)$.

The following summary of the distribution of cases is based on that given in the report of the County Medical Officer of Health for 1950:

Incidence was not unusual until August when there was a sharp rise in the weekly notifications. At first the districts chiefly affected were Newton Abbot U.D. and Teignmouth U.D., and there were three scattered cases in Newton Abbot R.D., and one or two in fourteen other districts. In September there was a localized outbreak of thirteen cases in Dartmouth U.D. (population 5,842). In October, there was another localized outbreak of eleven cases at Moretonhampstead, a small town (population about 1,500) on Dartmoor (Fig. 5, D1). Once again the districts of the N.W. had a relatively large number of cases but no localized outbreak.

1951-52, Cornwall.--Incidence declined in these years to $1 \cdot 1$ per 10,000 in 1951 , and 0.6 in 1952 . The main features were the persistence of cases in the Camborne, Redruth, and St. Austell areas, with a minor outbreak at St. Mawgan (St. Austell R.D.) of six cases during March-April, 1951, and the occurrence of four cases at Padstow in 1952.

1951-52, Devon.--Incidence declined to 1.0 per 10,000 in 1951 , but rose slightly to $1 \cdot 2$ in 1952 . Tavistock R.D. had eight notifications in 1951, but these were mostly scattered round Tavistock itself. In 1952, Newton Abbot U.D., the districts of the N.W. corner, and Sidmouth had an excessive number of notifications.

\section{Discussion}

The chief value of a study such as this may be to suggest ways in which the new tools of epidemiological investigation now becoming available may best be used. It would, for example, be interesting to know whether the outbreak in the small town of Fowey in 1950 was caused by a different strain of virus from that of 1949 or whether the two outbreaks were really one, with an intervening period of quiescence. One might even go further and speculate whether the Fowey outbreak of 1949 was associated with the prevalence in the neighbouring town of St. Austell in 1947.

The most suggestive facts which emerge from the survey are first the recurrence of the disease in certain areas, and secondly the fact that the big resorts do not seem to have played an obvious part in the genesis of epidemics in the two counties. There are a few areas which have enjoyed a remarkable freedom from the disease over the years. In Cornwall, St. Just U.D., and the Scilly Isles, and in Devon, South Molton U.D., have not had a notified case at least since 1931. These places. have very different social characteristics. The Scilly Isles are not very easily accessible from the mainland, but a fair number of holiday makers do go there in the spring and summer. St. Just is a small mining town where social conditions are poor, and South Molton is a market town on the main trunk road through North Devon (A.361). South Molton U.D. was a secondary focus in the epidemic of 1911 and is the most striking example of non-recurrence to be set against the examples of recurrence illustrated in Figs 2 and 5. It would be interesting to know whether the herd immunity in these places is different from that in areas of high incidence.

In the detailed notes on recent events in Cornwal attention has been drawn to certain occasions whe it has seemed that infection has persisted over $\vec{a}$ long period either in a family, or, in one instance, in a house. These have been mentioned because other observers of the disease may also have come across curious happenings of this kind. They seem quite inexplicable on the generally accepted theories of duration of infectivity and mode of spread, and they may be due to chance.

It is very difficult to formulate any epidemiological theory which will fit all the facts of distribution, ? though it is easy enough to select some of the facts and devise theories to suit them. For example, one might argue that the distribution of 1911 in the $\delta$ Administrative Counties suggested a low herd immunity in the rural population, but it is difficult $\frac{\text { 의 }}{7}$ to reconcile this argument with the high incidence $D$ in Plymouth. Again, one might argue that the relative freedom of these two western counties from $N$ the epidemic of 1947 suggests that a new virus was imported into eastern England in 1947 and took $N$ some time to show its effects in the West. It is, $\underset{\omega}{ }$ however, difficult to reconcile this argument with the distribution of those cases which did occur inco Devon and Cornwall in 1947.

Several examples have been given which make it $\stackrel{\oplus}{+}$ hard to believe that a localized epidemic generally ${ }^{0}$ 
ends because of the exhaustion of susceptibles. Fowey is the chief of these but Newton Abbot and the districts of the North coast are lesser ones.

As has been said, there is little evidence that epidemics start in the big resorts. It is, however, possible that there may be a silent building-up process in the big resort whilst the overt outbreak occurs much later in a smaller place.

In reviewing the facts of distribution in a general way, we are left with a general impression that a silent building-up period may be very important, and that the overt outbreak is the culmination of a process which may have been going on for some time, possibly for a year or two. This idea must remain pure speculation as long as the only indication we have of the presence of the virus is the occurrence of frank cases, but.when it becomes possible to look for the virus in apparently healthy populations and to investigate the antibody content of blood samples it may be possible to learn more about the genesis of outbreaks.

\section{SUMMARY}

(1) A study has been made of the distribution of notifications of poliomyelitis in Cornwall and Devon from 1911 to 1952.
(2) No direct evidence has been found of importation of infection from other parts of England into these two holiday counties.

(3) There is a suggestion that outbreaks tend to recur in the same, rather ill-defined areas, sometimes at intervals of many years, but there is no obvious social characteristic common to these areas.

Our thanks are due to the Medical Officers of Health of Cornwall and Devon, Exeter and Plymouth and to members of their staffs; to many District Medical Officers of Health and to Miss V. R. Harrison, A.R.I.B.A., who prepared the maps for us.

\section{REFERENCES}

Allen-Price, E. D. (1952). J. roy. sanit. Inst., 72, 443.

Benjamin, B., and Logan, W. P. B. (1953). British Journal of Preventive and Social Medicine, 7, 131.

Cornwall County Council Annual Reports of the County Medical Officer of Health, 1911-51.

Devon County Council Annual Reports, County Medical Officer, 1911-51.

Gregor, A., and Hopper, L. B. (1911). Brit. med. J., 2, 1154.

Hargreaves, E. R. (1949). Lancet, 1, 969.

Reece, R. J. (1912). "Reports to Local Government Board on Public Health and Medical Subjects", N.S. No. 61, p. 10. H.M.S.O., London.

Registrar-General Statistical Review of England and Wales, Part 1. Tables (Medical), 1921-51.

Serfling, R. E., and Sherman, I. L. (1953). Publ. Hlth Rep., Wash., 68, 453.

Soltau, A. B. (1911), Brit. med. J., 2, 1151.

APPENDIX TABLE

DEVON

\begin{tabular}{|c|c|c|c|c|c|c|c|c|c|c|c|c|}
\hline \multirow{2}{*}{\multicolumn{3}{|c|}{ Area }} & \multirow{2}{*}{$\begin{array}{c}\text { Population } \\
\text { Census } \\
1951\end{array}$} & \multirow{2}{*}{$\begin{array}{c}\text { Mean } \\
\text { Annual Rate } \\
\text { per } 10,000 \\
1947-52\end{array}$} & \multicolumn{6}{|c|}{ Number of Notifications in each Year } & \multirow{2}{*}{$\begin{array}{r}\text { Total } \\
1947-52 \\
\end{array}$} & \multirow{2}{*}{$\underset{5}{\text { Fig. }}$} \\
\hline & & & & & 1947 & 1948 & 1949 & 1950 & 1951 & 1952 & & \\
\hline $\begin{array}{c}\text { COUNTY BOROUGHS } \\
\text { Exeter } \quad \ldots\end{array}$ & . & .. & 75,479 & $1 \cdot 4$ & 10 & 6 & 6 & 25 & 4 & 10 & 61 & \\
\hline Plymouth & .. & . & 208,985 & $0 \cdot 8$ & 8 & 3 & 20 & 31 & 26 & 9 & 97 & \\
\hline $\begin{array}{c}\text { ADMINISTRATIVE Co } \\
\text { URBAN DISTRICTS } \\
\text { Ashburton } \\
\end{array}$ & $\begin{array}{l}\text { UNT } \\
. \\
\end{array}$ & - & 2,704 & $3 \cdot 7$ & 2 & 1 & - & 3 & 一 & - & 6 & 1 \\
\hline Axminster & .. & . & 2,673 & $4 \cdot 4$ & - & - & - & 7 & - & - & 7 & 1 \\
\hline Barnstaple & .. & $\because$ & 16,302 & $2 \cdot 2$ & 1 & - & 2 & 11 & 3 & 4 & 21 & 2 \\
\hline Bideford ... & .. & .. & 10,100 & $3 \cdot 1$ & - & - & 8 & 6 & - & 5 & 19 & 1 \\
\hline Brixham .. & .. & . & 8,761 & $1 \cdot 0$ & - & 一 & 1 & 3 & 1 & - & 5 & \\
\hline Buckfastleigh & .. & .. & 2,592 & 1.9 & - & 2 & - & 1 & - & - & 3 & 2 \\
\hline Budleigh ... & . & $\cdots$ & 3,953 & - & - & - & - & - & - & - & - & \\
\hline Crediton .. & .. & .. & 3,992 & $0 \cdot 8$ & - & 2 & - & - & - & - & 2 & \\
\hline Dartmouth & $\cdots$ & . & 5,842 & $4 \cdot 3$ & - & - & 1 & 13 & 1 & - & 15 & 1 \\
\hline Dawlish ... & .. & .. & 7,512 & $1 \cdot 6$ & 3 & 1 & 1 & 2 & - & - & 7 & 2 \\
\hline
\end{tabular}


APPENDIX TABLE-cont.

DEVON-cont.

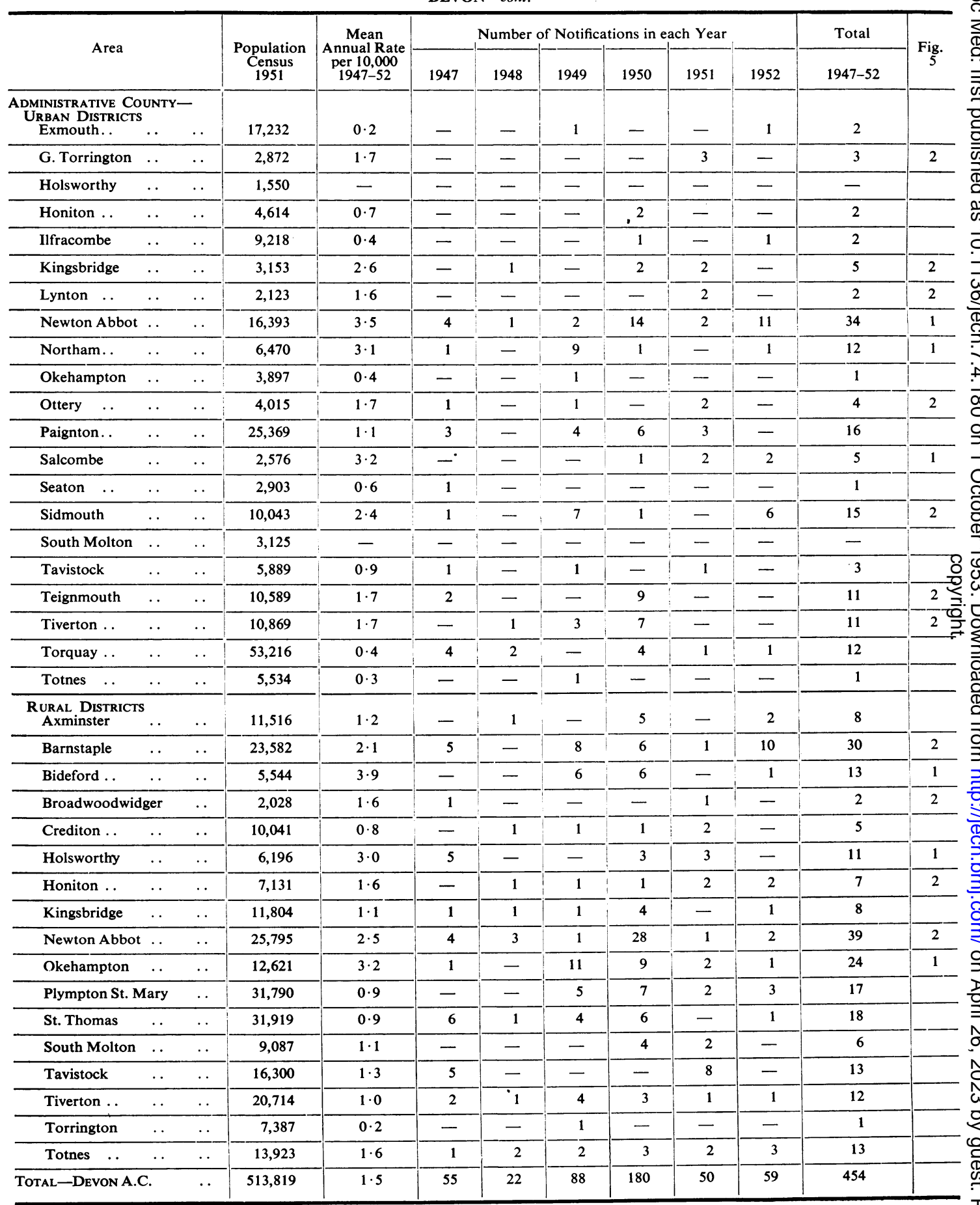


APPENDIX TABLE-cont. CORNWALL

\begin{tabular}{|c|c|c|c|c|c|c|c|c|c|c|c|c|}
\hline \multirow{2}{*}{\multicolumn{3}{|c|}{ Area }} & \multirow{2}{*}{$\begin{array}{c}\text { Population } \\
\text { Census } \\
1951\end{array}$} & \multirow{2}{*}{$\begin{array}{c}\text { Mean } \\
\text { Annual Rate } \\
\text { per } 10,000 \\
1947-52\end{array}$} & \multicolumn{6}{|c|}{ Number of Notifications in each Year } & \multirow{2}{*}{$\begin{array}{c}\text { Total } \\
1947-52 \\
\end{array}$} & \multirow{2}{*}{ Fig. } \\
\hline & & & & & 1947 & 1948 & 1949 & 1950 & 1951 & 1952 & & \\
\hline $\begin{array}{c}\text { URBAN DISTRICTS } \\
\text { Bodmin .. }\end{array}$ & . & $\cdots$ & 6,058 & - & - & 一 & - & 一 & 一 & - & 一 & \\
\hline Bude-Stratton & .. & $\cdots$ & 5,230 & $2 \cdot 9$ & - & - & 2 & 7 & - & - & 9 & 2 \\
\hline Camborne-Red & Iruth & $\cdots$ & 35,829 & $1 \cdot 8$ & 1 & 1 & 26 & 6 & 5 & - & 39 & 2 \\
\hline Flamouth & $\cdots$ & $\cdots$ & 17,036 & $1 \cdot 4$ & 1 & - & 3 & 8 & 1 & 1 & 14 & \\
\hline Fowey $\quad \ldots$ & $\cdots$ & $\cdots$ & 2,344 & $17 \cdot 1$ & - & - & 8 & 15 & 1 & - & 24 & 1 \\
\hline Helston .. & $\ldots$ & $\ldots$ & 5,545 & 0.6 & 1 & - & - & 1 & - & - & 2 & \\
\hline Launceston & $\ldots$ & $\ldots$ & 4,467 & $2 \cdot 2$ & 1 & - & 2 & 3 & - & - & 6 & 2 \\
\hline Liskeard . . & $\cdots$ & $\cdots$ & 4,391 & $1 \cdot 1$ & - & - & 1 & - & 1 & 1 & 3 & \\
\hline Looe $\quad \ldots$ & $\ldots$ & $\cdots$ & 3,801 & $3 \cdot 1$ & 2 & - & - & 4 & 1 & - & 7 & 1 \\
\hline Lostwithiel & $\cdots$ & $\cdots$ & 2,165 & $3 \cdot 9$ & 4 & - & 1 & - & - & - & 5 & 1 \\
\hline Newquay & $\cdots$ & $\cdots$ & 9,928 & $1 \cdot 5$ & 3 & - & 3 & 1 & 1 & 1 & 9 & \\
\hline Padstow .. & $\cdots$ & $\cdots$ & 2,852 & $3 \cdot 5$ & - & - & - & 2 & - & 4 & 6 & 1 \\
\hline Penryn $\ldots$ & $\ldots$ & $\cdots$ & 4,088 & $2 \cdot 5$ & - & - & 1 & 4 & 1 & - & 6 & 2 \\
\hline Penzance.. & . & $\cdots$ & 20,648 & $1 \cdot 3$ & - & 2 & 9 & 2 & - & 3 & 16 & \\
\hline St. Austell & $\cdots$ & $\cdots$ & 23,634 & $1 \cdot 6$ & 9 & 2 & 4 & 3 & 3 & 1 & 22 & 2 \\
\hline St. Ives $\quad \ldots$ & $\cdots$ & $\cdots$ & 9,037 & $1 \cdot 3$ & 2 & - & 3 & 1 & - & 1 & 7 & $\div$ \\
\hline St. Just $\quad \ldots$ & $\cdots$ & $\cdots$ & 4,122 & - & - & - & - & - & - & - & - & \\
\hline Saltash $\quad \ldots$ & $\cdots$ & $\ldots$ & 7,924 & $1 \cdot 1$ & - & 1 & - & 2 & 2 & - & 5 & \\
\hline Torpoint. . & $\ldots$ & $\cdots$ & 5,852 & $0 \cdot 3$ & - & - & - & 1 & - & - & 1 & \\
\hline Truro City & $\cdots$ & $\cdots$ & 12,851 & $3 \cdot 4$ & - & 3 & 19 & 1 & 1 & 2 & 26 & 1 \\
\hline $\begin{array}{l}\text { RURAL DisTricTS } \\
\text { Camelford }\end{array}$ & .. & $\cdots$ & 7,577 & 0.4 & - & - & 1 & 1 & - & 一 & 2 & \\
\hline Kerrier .. & $\cdots$ & $\cdots$ & 21,807 & 0.8 & - & - & 1 & 8 & 2 & - & 11 & \\
\hline Launceston & $\cdots$ & $\cdots$ & 6,491 & $0 \cdot 8$ & - & - & 1 & 1 & 1 & - & 3 & \\
\hline Liskeard .. & $\cdots$ & $\cdots$ & 14,312 & 0.9 & 3 & 1 & 1 & 3 & - & - & 8 & \\
\hline St. Austell & $\cdots$ & $\cdots$ & 20,833 & $1 \cdot 8$ & 2 & 3 & 5 & 4 & 7 & 1 & 22 & 2 \\
\hline St. Germans & $\cdots$ & $\cdots$ & 16,845 & $1 \cdot 0$ & 1 & 4 & - & 4 & 1 & - & 10 & \\
\hline Stratton .. & $\cdots$ & $\cdots$ & 6,122 & $4 \cdot 9$ & 2 & - & 3 & 10 & 1 & 2 & 18 & 1 \\
\hline Truro $\quad \ldots$ & $\cdots$ & . & 27,296 & $1 \cdot 1$ & 1 & - & 12 & 1 & 2 & 2 & 18 & \\
\hline Wadebridge & $\cdots$ & $\cdots$ & 16,146 & $0 \cdot 8$ & - & 1 & 1 & 2 & 3 & 1 & 8 & \\
\hline West Penwith & $\ldots$ & $\ldots$ & 18,216 & $1 \cdot 3$ & 3 & 1 & 4 & 3 & 2 & 1 & 14 & \\
\hline Scilly Isles & $\cdots$ & $\cdots$ & 2,165 & - & - & - & - & - & - & - & - & \\
\hline TOTAL-CORNWALL & A.C. & $\cdots$ & 345,612 & $1 \cdot 6$ & 36 & 19 & 111 & 98 & 36 & 21 & 321 & \\
\hline
\end{tabular}

